\title{
FUNCTIONAL COATINGS ON VALVE METALS IN SURFACE TREATMENT TECHNOLOGIES ${ }^{1}$
}

\author{
Karakurkchi H. V., Sakhnenko M. D.
}

\section{INTRODUCTION}

Currently an intensive development of technologies is aimed at improving the operational properties of metals and alloys by modifying their surface. One of the most popular and promising for valve metals proceeding is the method of plasma electrolytic oxidation $(\mathrm{PEO})^{2}$. It allows the formation of oxide coatings with enhanced mechanical, corrosive and catalytic properties ${ }^{3}$. Among the advantages of PEO, it is worth noting the non-toxicity of the electrolytes used, the simplicity and compactness of the operating equipment, the absence of a preliminary surface preparation stage, the possibility of processing products of large mass and complex geometry. Changes in the oxidation conditions, the type and composition of the electrolyte, especially the nature of the additive components (dopants), allow us to vary the composition and properties of the formed oxide layers. A significant number of publications in the world and domestic scientific literature indicates the relevance and prospects of research in this area. At the same time, the majority of scientific investigations and developments presented to the general public are aimed primarily at solving limited technological issues and are not systemic in nature, which limits the widespread implementation of PEO in mass production.

The presented paper discusses the features of the conversion coatings formation on aluminum and titanium alloys by plasma electrolytic oxidation in alkaline electrolytes. It is devoted to a detailed analysis of the effect of mixed cobalt and/or manganese oxides composition on the morphology,topography and the structure of the surface layers formed by

${ }^{1}$ This research was conducted with the support of the Ministry of Education and Science of Ukraine within the confines of the project (Registration Number 0119U002568).

${ }^{2}$ Gupta P., Tenhundfeld E.O., Daigle D., Ryabkov G.Electrolytic plasma technology: Science and engineering - An overview. Surface and Coatings Technology. 2007. Vol. 201. Issue 21. P. 8746-8760. DOI: 10.1016/j.surfcoat.2006.11.023.

${ }^{3}$ Rudnev V.S., Lukiyanchuk I.V., Vasilyeva M.S., Medkov M.A., Adigamova M.V., Sergienko V.I. Aluminum- and titanium-supported plasma electrolytic multicomponent coatings with magnetic, catalytic, biocide or biocompatible properties. Surface \& Coatings Technology. 2016. Vol. 307. Part C. P. 1219-1235. DOI: 10.1016/j.surfcoat.2016.07.060 
PEO treatment on above alloys. Also, the prospects for their application in technology of toxic substances neutralization are discussed.

\section{Features of the PEO coatings formation on valve metals}

Physic-chemical and mechanical properties of metals significantly depend on their composition and the ratio of basic and alloying elements. Intermetallic compounds of various compositions contained in $\mathrm{Al}$ and $\mathrm{Ti}$ alloys as hardening phases change not only their properties, but also strongly affect the surface treatment process, including the formation of conversion and other coatings. The presence of these compounds in the surface layer of the processed material leads to a change in its electrochemical properties. This must be considering when substantiating the composition of electrolyte solutions and developing PEO technological modes for $\mathrm{Al}$ and $\mathrm{Ti}$ alloys surface treatment.Also, it should be noted that a feature of the PEO method is the possibility of incorporation into the composition of the conversion oxide layers the components of metal to be treated, electrolyte ingredients, as well as products of their electrochemical and thermochemical transformations ${ }^{4}$. Therefore, by controlling the chemical composition of the oxide layers, it is possible to significantly improve the functional properties of the metal being processed, as well as expand the scope of their application ${ }^{5}$. Early studies have shown a rather complex mechanism of reactions multicomponent valve metal alloys oxidation in the solutions and the feasibility of using complex electrolytes based on diphosphates for $\mathrm{PEO}^{6}$.Manganese and cobalt were selected as dopants to the mixed oxidestaking into account their polyvalency and unique physic-chemical properties. It was proposed to use $\mathrm{KMnO}_{4}$ as an electrode-active substance to dope oxide coatings with manganese. This approach is the result of our studies, which showed that it is impossible to obtain coatings with a high content of manganese oxides from solutions with the addition of Mn (II) salts. It is proposed to use diphosphate electrolytes with $\mathrm{CoSO}_{4}$ additives for cobalt incorporation into the mixed oxide layers.

Also, in previous studies it was found that the concentration ratio of dopant salt and ligand affects the operating parameters of the oxidation process and allows the formation of coatings with a variable content of the

${ }^{4}$ Malyshev, V.N., Zorin, K.M. Features of Microarc Oxidation Coatings Formation Technology in Slurry Electrolytes.Applied Surface Science. 2007. № 254 (5). P. 1511-1516. DOI: 10.1016/j.apsusc.2007.07.079.

5 Suminov, I.V., Belkin, P.N., Epelfeld, A.V., Lyudin, V.B., Krit, B.L., Borisov, A.M. Plazmenno-elektroliticheskoe modifitsirovanie poverhnosti metallov i splavov. Moskow : Tehnosfera, 2011. T. 1. 464 p.

${ }^{6}$ Sakhnenko N.D., Ved M.V., Karakurkchi A.V. Nanoscale Oxide PEO Coatings Forming from Diphosphate Electrolytes. Springer Proceedings in Physics. 2017. P. 507-531. DOI: 10.1007/978-3-319-56422-7_38. 
doping component ${ }^{7,8}$. For further studies, the composition of the electrolytes was selected to provide the formation of cobalt and/or manganese enriched oxide layers with a high degree of surface development.

Oxide coatings were formed on substrates made of $\mathrm{Al}$ and $\mathrm{Ti}$ alloys in electrolytes of composition given in the Table 1. Certified reagents of chemically pure grade, and distilled water were used for the working solutions preparing. The surface of samples for oxidizing was prepared by grinding with subsequent degreasing, washed with cold and hot water, dried at a temperature of $20-30^{\circ} \mathrm{C}$.

Table 1

The composition of electrolytes for PEO of valve metals

\begin{tabular}{|c|c|c|}
\hline \multicolumn{2}{|c|}{ Electrolyte } & \multirow{2}{*}{ Substrate } \\
\hline Composition & Concentration, $\mathrm{mol} / \mathrm{dm}^{3}$ & \\
\hline $\mathrm{K}_{4} \mathrm{P}_{2} \mathrm{O}_{7}$ & 0.4 & \multirow{4}{*}{ Al alloys: AD0, D16, AMn, AL25 } \\
\hline $\mathrm{CoSO}_{4}$ & 0.1 & \\
\hline $\mathrm{NaOH}$ & 0.005 & \\
\hline $\mathrm{KMnO}_{4}$ & 0.05 & \\
\hline $\mathrm{K}_{4} \mathrm{P}_{2} \mathrm{O}_{7}$ & 1.0 & \multirow{4}{*}{ Ti alloys: VT1-0, OT4-1 } \\
\hline $\mathrm{KMnO}_{4}$ & 0.1 & \\
\hline $\mathrm{K}_{4} \mathrm{P}_{2} \mathrm{O}_{7}$ & 0.5 & \\
\hline $\mathrm{CoSO}_{4}$ & 0.1 & \\
\hline
\end{tabular}

PEO was conducted in a galvanostatic mode using of a constant-current source B5-50. The mode of direct current (dc) ensures to the "healing" of defects in oxide coatings and to obtain surface layers of a more uniform morphology. The current density was varied in the range of $2-20 \mathrm{~A} / \mathrm{dm}^{2}$. The electrolyte temperature was maintained within the interval of $20-30^{\circ} \mathrm{C}$. Processing time was $30-60 \mathrm{~min}$.

It was established that the chronograms of voltage changing when forming the oxide coatings on aluminum and titanium acquire a classic shape and are divided into specific regions (Fig. 1) ${ }^{9}$. Sector I corresponds to the formation the phase oxides of base metal obeying the electrochemical mechanism; sector II reflects the local breakdown of the oxide film and the initiation of sparking in the discharge channel. Site III is characterized by the

\footnotetext{
${ }^{7}$ Yar-Mukhamedova, G.Sh., Ved, M.V., Karakurkchi, A.V., Sakhnenko, N.D. Mixed alumina and cobalt containing plasma electrolytic oxide coatings. IOP Conference Series: Materials Science and Engineering. 2017. Vol. 213. DOI: 10.1088/1757899X/213/1/012020.

8 Yar-Mukhamedova G., Ved M., Karakurkchi A., Sakhnenko N., Atchibayev $\mathrm{R}$. Research on the improvement of mixed titania and Co (Mn) oxide nano-composite coatings. IOP Conference Series: Materials Science and Engineering. 2018. Vol. 369. DOI: 10.1088/1757-899X/369/1/012019.

9 Terleeva O.P., Belevantsev V.I., Slonova A.I., Boguta D.L., Rudnev V.S. Comparison analysis of formation and some characteristics of microplasma coatings on aluminum and titanium alloys. Protection of Metals. 2006. Vol. 42. № 3. P. 272-278. DOI: $10.1134 / \mathrm{S} 0033173206030106$.
} 
voltage $U$ fluctuations depending both on the processed metal nature and the electrolyte composition; region IV detects the condensation and polymorphic transformations of oxide phases followed by transition to the arc regime and destruction of oxide layers.

The dependence of $U-t$ in the pre-spark region (Fig. 1, I) is almost linear due to the formation of a barrier oxide of base metal (aluminum or titanium) with increasing thickness and, accordingly, resistance. At the beginning of sparking (Fig. 1, I-II) voltage growth is inhibited due to competing breakdown and regeneration of barrier oxide. But at the same time thermochemical reactions occur that ensure the incorporation of the electrolyte components into the matrix of formed oxide layers. Therefore, the time before the onset of sparking and the initial sparking voltage should depend on the nature of the treated material.

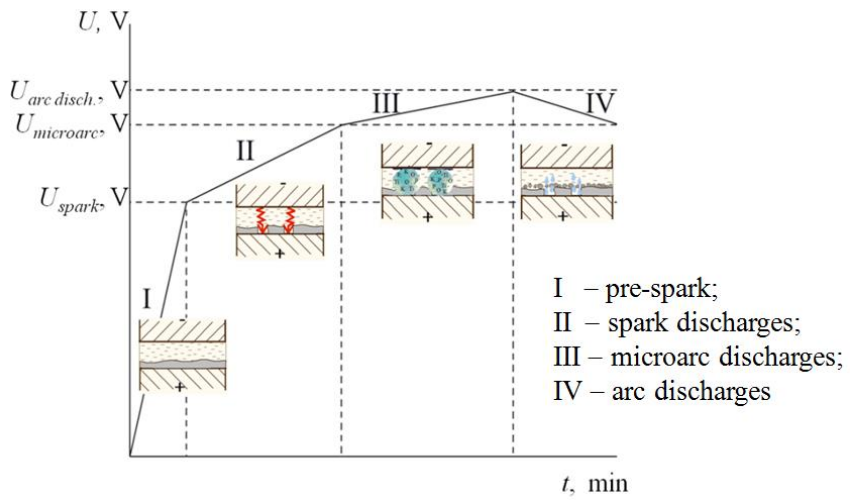

Figure 1. Characteristic of PEO stages during treatment of valve metals

Indeed, for titanium alloys PEO treatment in the electrolytes (Table 1) thetime of initial sparkingdoes not exceed $2 \mathrm{~min}$, and $U$ of initial sparking is of 65-70 V. Sparking at PEO aluminum alloys in electrolytes begins in 5-8 minutes, and the $U_{\text {spark }}$ is of $110-120 \mathrm{~V}$. This is due to the higher specific electric resistance of aluminum oxides compared to titanium ones, as well as the presence of a large number of alloying impurities and alloying components effects the parameters of PEO. The stabilization of the PEO process occurs in the field of steady sparking (Fig. 1, II), the sparking voltage $U_{\text {spark }}$ for Ti alloys is in the range of $120-130 \mathrm{~V}$, and for the $\mathrm{Al}$ alloy $U_{\text {spark }}$ reaches $140-180 \mathrm{~V}$ depending on the type of electrolyte. At the same time, for alloys with a lower content of impurities, the indicators of PEO 
stages are slightly lower than for complex alloyed systems ${ }^{10}$. The incorporation of electrolyte components into the composition of surface layer on this stage is visualized by the appearance of areas of arbitrary purple (for cobalt) and black (for manganese) color.

In the micro-arc mode (Fig. 1, III), the concentration of incorporated dopants into the matrix of formed oxides increases significantly, and they gradually cover the entire surface of the treated sample. Under these conditions, the processing voltage is almost unchanged. However, for both aluminum and titanium alloys treatment in different electrolytes, slight voltage oscillations are observed independent on PEO current density. This can be explained by the formation of oxide systems with different resistivity and thermal resistance. At the same time, the most powerful micro arcs can break the surface and destroy the oxide layer, so it is necessary to provide the PEO process within sections II-IV.

Experimental studies have shown that the implementation of such a route for alloyed aluminum alloys is achieved by the mode of "falling" power ${ }^{11}$. In the first step, a higher initial current density is applied to accelerate the formation of the barrier oxide film. After entering the steady spark mode, the current density is reduced to stabilize the process in the voltage range corresponding to the sections II-IV and to form a uniform mixed oxide.

For cobalt-pyrophosphate solutions, the current density of the PEO at the first stage does not exceed $10 \mathrm{~A} / \mathrm{dm}^{2}$, and at the second step must be maintained in the interval of $2-5 \mathrm{~A} / \mathrm{dm}^{2}$. For alkaline permanganate electrolytes, the oxidation in the first stage is more effectively realized at a current density of $15-25 \mathrm{~A} / \mathrm{dm}^{2}$, the second PEO stage proceeds at $5-15 \mathrm{~A} / \mathrm{dm}^{2}$. The characteristic voltages of the aluminum alloy PEO process also depend on the type and composition of the electrolyte. These differences are explained by the peculiarities of the course of electrochemical and thermo-chemical processes involving $\mathrm{Co}^{2+}$ and $\mathrm{MnO}_{4}^{-12}$. The study results helped to establish that the characteristics of valve metals PEO-treatment stages depend on the nature of the treated material and the electrolyte composition. Important for a technique for composite oxide coatings formation onto the surface of $\mathrm{Al}$ and $\mathrm{Ti}$ alloys are the voltage characteristics change during oxidation of the base metal (Figure 2).

${ }^{10}$ Sakhnenko M.. Ved' M.. Gorohivskiv A.. Galak O.. Menshov S.. Matvkin O. Cobalt and manganese oxide catalytic systems on valve metals in ecotechnologies. Promising Materials and Processes in Applied Electrochemistry : monograph / editor-inchief V.S. Barsukov. Kyiv, 2017. P. 214-223.

11 Ved M.V., Karakurkchi A.V., Sakhnenko N.D., Gorohivskiy A.S. Synthesis of catalytic cobalt-containing coatings on alloy AL25 surface by plasma electrolytic oxidation. Chemistry, Physics and Technology of Surface. 2017. Vol. 8. № 1. P. 73-79. DOI: $10.15407 / \mathrm{hftp} 08.01 .073$

${ }^{12}$ Sakhnenko N.D., Ved' M.V., Luhovskyi I.S., Drobakha H.A., Mayba M.V. Features of plasma electrolytic formation of manganese- And cobalt-containing composites on aluminum alloys. Advances in Materials Science and Engineering. 2019. Vol. 2019. Article ID 6381291. 13 p. DOI: 10.1155/2019/6381291. 


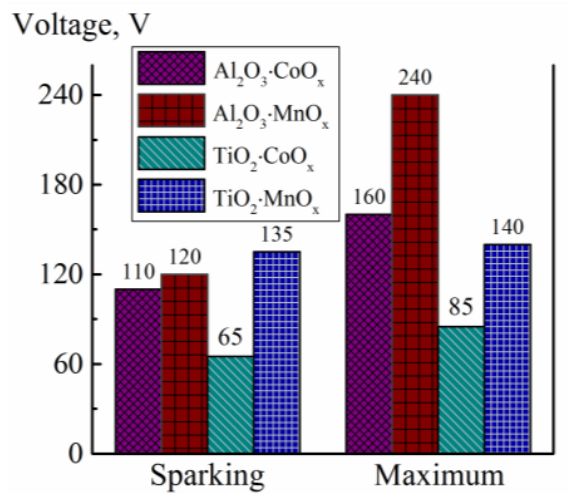

Figure 2. Voltage characteristics at the stages of PEO for $\mathrm{Al}$ and $\mathrm{Ti}$ alloys

The difference in the parameters of plasma-electrolytic treatment of valve metals during the oxide coatings formation on $\mathrm{Al}$ and $\mathrm{Ti}$ alloys is explained by the different electric resistance of matrix oxides $\left(\mathrm{Al}_{2} \mathrm{O}_{3}\right.$ and $\mathrm{TiO}_{2}$ ). In addition, the $\mathrm{Al}$ alloys (AMn, AL25) contains a significant amount of alloying components in composition, which also affects characteristics of the PEO stages ${ }^{13}$. That is why PEO of the Ti alloys (VT1-0, OT-4) is characterized by a less period for entering the sparking regime and by lower level operating voltages during treatment process.

\section{Functional coatings on aluminum alloys}

So, it is possible to obtain ceramic-like oxide coatings incorporating with cobalt or manganese oxides when treated $\mathrm{Al}$ alloys in PEO mode in alkaline electrolytes with the additives due to the simultaneous realization of electrochemical oxidation of the substrate and the dopants cations, and thermal decomposition of the electrolyte components ${ }^{14}$.

Functional coatings $\mathrm{Al}_{2} \mathrm{O}_{3} \cdot \mathrm{CoO}_{\mathrm{x}}$

Feature of $\mathrm{PEO}$ of $\mathrm{Al}$ alloys in alkaline diphosphate electrolytes is anodic dissolution of alloying components of the processing material.As a result,

${ }^{13}$ Karakurkchi A., Sakhnenko M., Ved M., Galak A., Petrukhin S. Application oxidemetal catalysts on valve metals in environmental catalysis. Eastern-European Journal of Enterprise Technologies. Materials Science. 2017. № 5/10(89). P. 12-18. DOI:10.15587/1729-4061.2017.109885.

i4 Rogov A.B. Plasma electrolytic oxidation of A1050aluminium alloy in homogeneous silicate-alkaline electrolytes with edta 4-complexes of $\mathrm{Fe}, \mathrm{Co}, \mathrm{Ni}, \mathrm{Cu}, \mathrm{La}$ and $\mathrm{Ba}$ under alternating polarization conditions. Materials Chemistry and Physics. 2015. Vol. 167. P. 136-144. DOI: 10.1016/j.matchemphys.2015.10.020. 
the surface is homogenized and the preconditions for the incorporation of the dopant $(\mathrm{Co})$ into the oxide layer are created.

The morphology of the formed oxide coatings surface was studied using the scanning electron microscope ZEISS EVO 40XVP (Germany). Chemical composition of the oxide coatings was determined on energy-dispersion spectrometer Oxford INCA Energy 350 (Great Britain) with the integrated program environment SmartSEM.

During the PEO process, cobalt incorporation into the composition of oxide layers occurs in the form of drop-shaped and spherical inclusions agglomerates of spherical islet of blue-purple color (Figure 3 ).

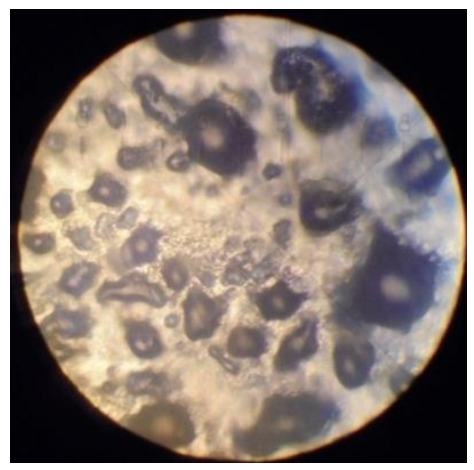

Figure 3. The morphology of $\mathrm{Al}_{2} \mathrm{O}_{3} \cdot \mathrm{CoO}_{x}$ coating

The variation the operating current densityaffects the change in the morphology and chemical composition of the coatings surface (Figure 4). With an increase in oxidation current density from 3 to $5 \mathrm{~A} / \mathrm{dm}^{2}$, spherical islet number increases, they form mosaic structures and evenly cover the entire surface of the treated metal. As a result of PEO of $\mathrm{Al}_{2} \mathrm{O}_{3}$ matrix with incorporated remelts of the components of electrolyte is formed. PEO of samples at current density of $10 \mathrm{~A} / \mathrm{dm}^{2}$ leads to Co incorporation in the form of voluminous islet structures.

Given a quite rapid transition of PEO into the arc mode, there is a tendency to these inclusions peeling off from the basis. The coating with the highest Co content was obtained at current density of $5 \mathrm{~A} / \mathrm{dm}^{2}$. Minimal inclusion of $\mathrm{Co}$ is ensured in the oxidation process at current density 10 $\mathrm{A} / \mathrm{dm}^{2}$. So, high densities of the oxidation current results in the formation of a more developed structure of the oxide surface ${ }^{15}$.

${ }^{15}$ Walsh F.C., Low C.T.J., Wood R.J.K., Stevens K.T., Archer J., Poeton A.Rl. Plama electrolytic oxidizing (PEO) for production of anodised coatings on lightweight metal (Al, $\mathrm{Mg}$, Ti) alloys. Transactions of the Institute of Metal Finishing. 2009. Vol. 87. № 3. P. 122-135. DOI:10.1179/174591908X372482. 


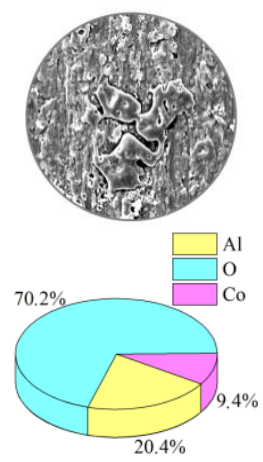

a
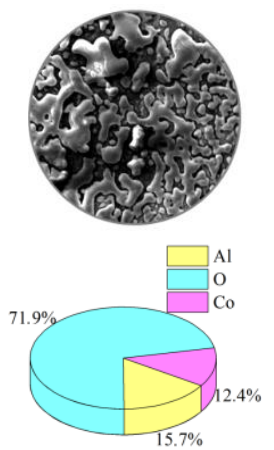

b


c

Figure 4. Surface morphology and composition (at. \%) of $\mathrm{Al}_{2} \mathrm{O}_{3} \cdot \mathrm{CoO}_{x}$ coatings, obtained at current density, $\mathrm{A} / \mathrm{dm}^{2}: a-3 ; b-5 ; c-10$.

Magnification $\times \mathbf{5 0 0}$

Variation in time of PEO-treatment of $\mathrm{Al}$ alloy also makes it possible to obtain oxide coatings of different morphology and composition. With an increase in PEO time from 20 to $40 \mathrm{~min}$ the surface morphology of coatings changes from unevenly rough to uniformed mosaic (Figure 5, $a$ ) and further to globular-mosaic (Figure 5, b). PEO within $60 \mathrm{~min}$ or more leads to "overgrowing" of the voluminous structure and its alignment (Figure 5,c).


a

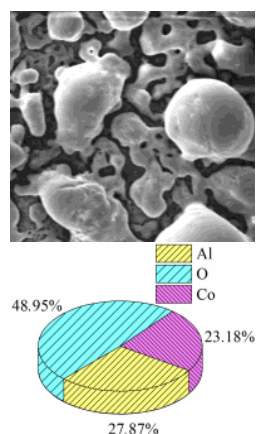

$\mathrm{b}$



C

Figure 5.Surface morphology and composition (at.\%) of $\mathrm{Al}_{2} \mathrm{O}_{3} \cdot \mathrm{CoO}_{x}$ coatings, obtained at different PEO time, min: $a-20 ; b-40 ; c-60$. Magnification 1000 
Analysis of the chemical composition of the obtained oxide structures indicates enrichment of the surface layer with cobalt directly in the formed globules.

The obtaining ceramic-like coating has good adhesion to the substrate and the high level of surface development.This is confirmed by the results of surface topography analysis using the atomic force microscope NT-206, probe CSC-37, and cantilever $\mathrm{B}$. The surface of oxide coatings $\mathrm{Al}_{2} \mathrm{O}_{3} \cdot \mathrm{CoO}_{x}$ (Figure 6) has a globular structure and consists of grain agglomerates.

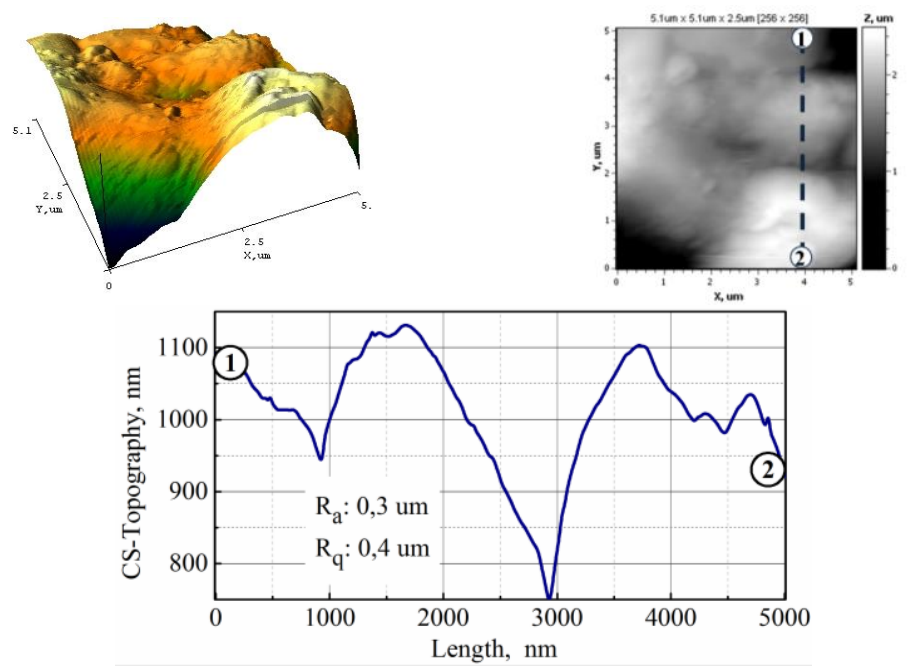

Figure 6. 3D- and 2D-surface maps and cross section between markers 1 and $20 \mathrm{Al}_{2} \mathrm{O}_{3} \cdot \mathrm{CoO}_{x}$ coating. The scan area is $5 \times 5 \mu \mathrm{m}$

Indicators of roughness of obtained coatings $R_{a}$ and $R_{q}$ are in the range of $0.3-0.4$ um in the studied scan area.

The structure of the deposits was examined by X-ray diffraction analysis using a diffractometer DRON-2.0 in monochromatic $\mathrm{Co}-\mathrm{K} \alpha$ radiation $(\lambda=1.7902 \mathrm{~A})$. The phase identification was carried out by comparing the distance between the planes $(\mathrm{d}, \mathrm{A})$ and the relative intensities of the experimental curve with the data of the electronic file system PCPDFWIN.

The results of the $\mathrm{X}$-ray analysis confirm that the formed oxide coatings consist of $\alpha-\mathrm{Al}_{2} \mathrm{O}_{3}$ with incorporated oxides $\mathrm{Co}_{3} \mathrm{O}_{4}$ (Figure 7).

After calcination of oxide coating $\mathrm{Al}_{2} \mathrm{O}_{3} \cdot \mathrm{CoO}_{\mathrm{x}}$ at a temperature of $600^{\circ} \mathrm{C}$, the number of peaks corresponding to cobalt oxides increases. The intensity of the oxide lines of Co depends on the quantitative composition of the oxide layer. 


\section{$\mathrm{I}, \mathrm{imp} / \mathrm{s}$}

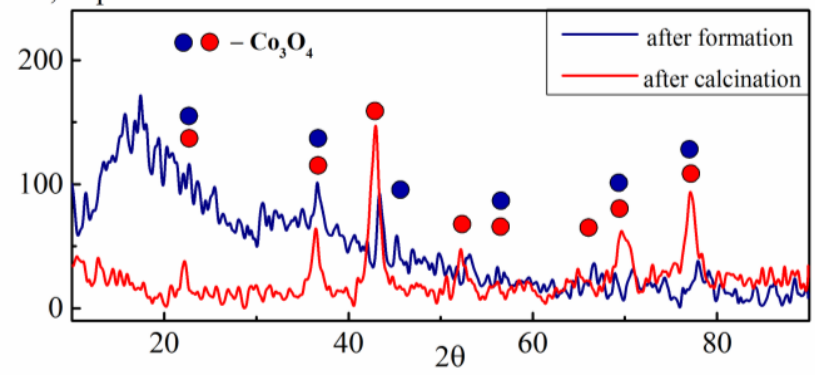

Figure 7. X-ray patterns of $\mathrm{Al}_{2} \mathrm{O}_{3}, \mathrm{CoO}_{x}$ oxide coating on aluminum alloys

The features of the phase structure together with the developed surface and significant content of cobalt oxides are a prerequisite for increasing the functional properties of oxide coatings ${ }^{16}$.

Functional coatings $\mathrm{Al}_{2} \mathrm{O}_{3} \cdot \mathrm{MnO}_{\mathrm{x}}$

PEO-treatment of the Al alloys in electrolytes with manganeseallows obtain a surface layer of micro-globular structure (Figure 8).

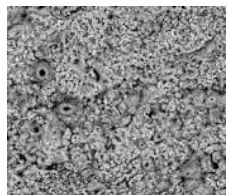

AD0

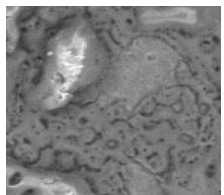

D16

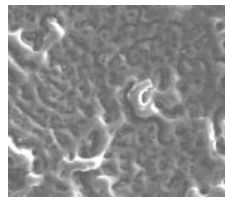

AMn

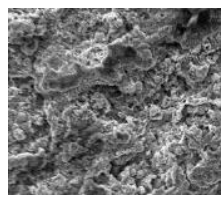

AL25

Figure 8. The surface morphology of the oxide coatings $\mathrm{Al}_{2} \mathrm{O}_{3} \cdot \mathrm{MnO}_{\mathrm{x}}$. on aluminum alloys. Magnification $\times \mathbf{1 0 0 0}$

It was established in the course of conducted experiments that the variation of PEO conditions makes it possible to control the process of synthesis of oxide-metallic composition in the matrix of oxide of the base metal. High densities of the oxidation current results in the formation of a more developed structure of the oxide surface (Figure 9). This is also an additional factor in the formation of a better developed surface of catalysts by modifying energy parameters of the oxidization process.

${ }^{16}$ Ved' M.V., Sakhnenko N.D., Karakurkchi A.V., Myrna T.Yu. Functional mixed cobalt and aluminum oxide coatings for environmental safety. Functional Materials. 2017. Vol. 24. № 2. P. 303-310. DOI:10.15407/fm24.02.303. 

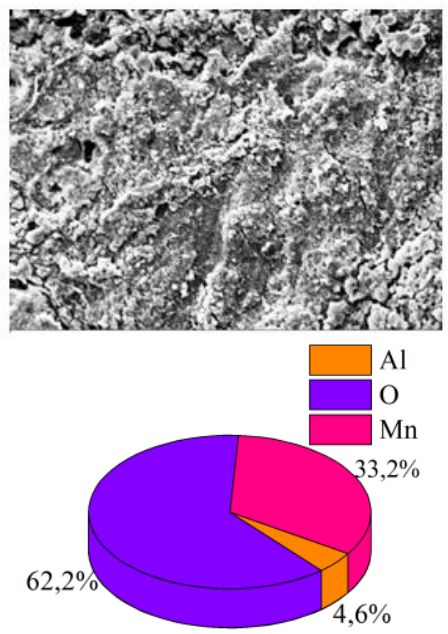

a


b

Figure 9. Effect of current density on the morphology and composition of oxide coatings $\mathrm{Al}_{2} \mathrm{O}_{3} \cdot \mathrm{MnO}_{\mathrm{x}}: a-15 \mathrm{~A} / \mathrm{dm}^{2}$, $b-20 \mathrm{~A} / \mathbf{d m}^{2}$.Magnification $\times 1000$

The content of manganese in oxide coatings increases with an increase in the current density of forming ${ }^{17}$. The results of chemical analysis indicate that the surface oxide layer mainly consists of $\mathrm{MnO}_{\mathrm{x}}$ and contains up 36 at.\% of $\mathrm{Mn}$.

The study of morphology and chemical composition of the surface layers makes it possible to conclude that PEO-treatment of aluminum alloys in alkaline electrolytes with addition of $\mathrm{KMnO}_{4}$ leads to formation of a sufficiently developed voluminous structure.

Oxide coatings $\mathrm{Al}_{2} \mathrm{O}_{3} \cdot \mathrm{MnO}_{\mathrm{x}}$ are uniform, have low-porosity, high adhesion to the substrate. A high degree of surface development of the oxide coatings is confirmed by the results of the study of topography of surface layers using AFM (Figure 10).

17 Egorkin V.S., Vyaliy I.E., Sinebryukhov S.L., Gnedenkov S.V. Composition, morphology and tribological properties of PEO-coatings formed on an aluminum alloy D16 at different duty cycles of the polarizing signal. Non-ferrous Metals. 2017. Vol. 42. № 1. P. 12-16. 

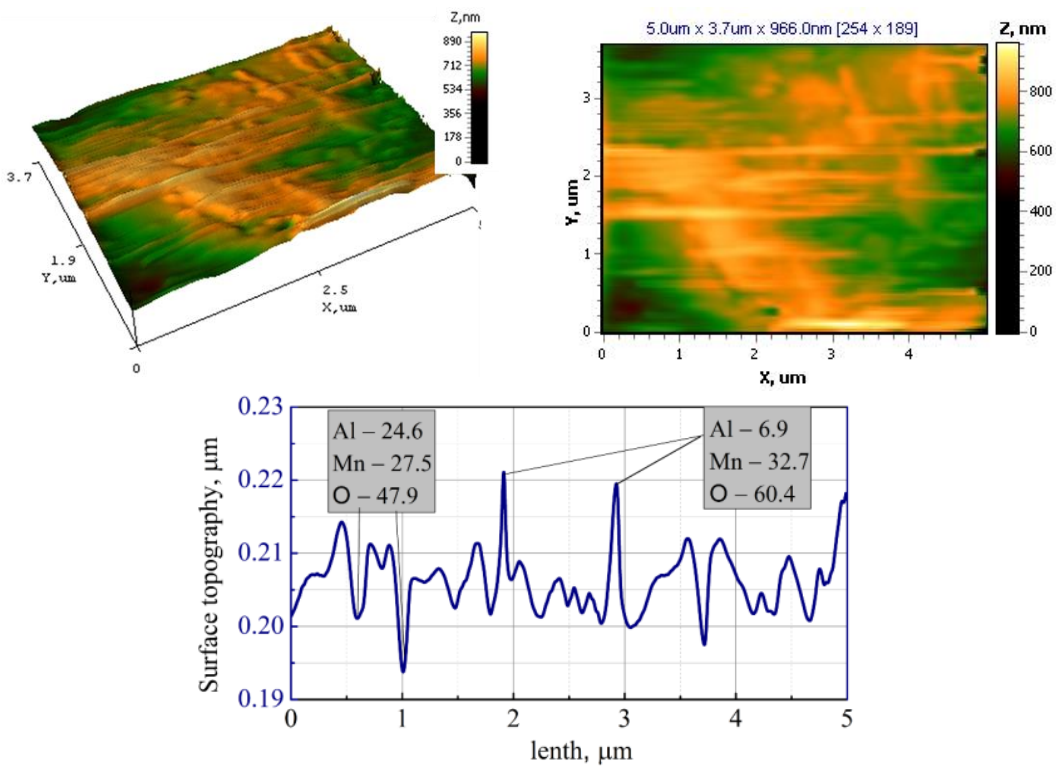

Figure 10.3D- and 2D-surface maps and cross section of $\mathrm{Al}_{2} \mathrm{O}_{3} \cdot \mathrm{MnO}_{\mathrm{x}}$ coating. The scan area is $5 \times 5 \mu \mathrm{m}$

The surface of $\mathrm{Al}_{2} \mathrm{O}_{3} \cdot \mathrm{MnO}_{\mathrm{x}}$ has a micro-globular structure. The oxide coatings with $\mathrm{Mn}$ are characterized by the formation of the cone-shaped conglomerates with an average diameter of $80-100 \mathrm{~nm}$, and the difference of hills and valleys does not exceed $200 \mathrm{~nm}$. The surface of $\mathrm{Al}_{2} \mathrm{O}_{3} \cdot \mathrm{MnO}_{\mathrm{x}}$ is characterized by the sufficiently uniform distribution of $\mathrm{Mn}^{18}$.

On X-ray diffraction pattern of $\mathrm{Al}_{2} \mathrm{O}_{3} \cdot \mathrm{MnO}_{\mathrm{x}}$ coatingalso revealed an amorphous halo at angles $2 \theta \sim 20^{\circ}$, due to the peculiarities of formation an oxide PEO structure under non-equilibrium conditions ${ }^{19}$ (Figure 11).

${ }^{18}$ Sakhnenko N.D., Ved M.V., Androshchuk D.S., Korniy S.A. Formation of coatings of mixed aluminum and manganese oxides on the AL25 alloy.Surface Engineering and Applied Electrochemistry. 2016. Vol. 52. № 2. P. 145-151. DOI: 10.3103/s1068375516020113.

${ }^{19}$ Yerokhin A.L., Nie X., Leyland A., Matthews A., Dowey S.J. Plasma electrolysis for surface engineering. Surface and Coating Technology. 1999. Vol. 122. № 2-3. P. 73-93. DOI: 10.1016/s0257-8972(99)00441-7. 




Figure11.X-ray patterns of $\mathrm{Al}_{2} \mathrm{O}_{3} \cdot \mathrm{MnO}_{\mathrm{x}}$ coating on aluminum alloy

It should be noted that after annealing the formed coatings at a temperature of $600^{\circ} \mathrm{C}$, there is a change in the structure of the coatings, in particular, the amorphous halo disappears. The proportion of $\mathrm{Mn}_{3} \mathrm{O}_{4}$ oxides with higher thermal resistance is also increasing.

The composition, morphology, topography and surface structure of the mixed oxide coatings on the $\mathrm{Al}$ alloys are a prerequisite for improving their functional properties.In particular, the PEO-systems doped with Co and Mn show an increased corrosion resistance (Figure 12).

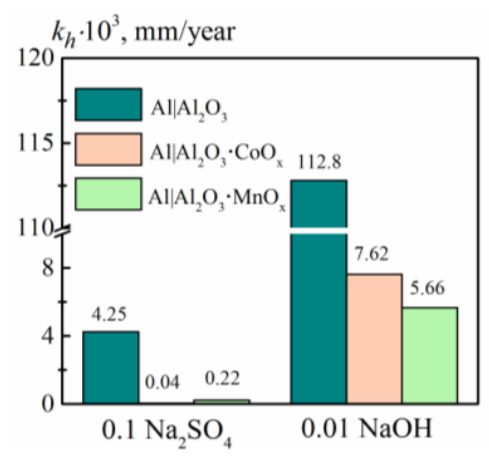

\section{Figure 12. Deep corrosion index, $k_{h}$ of oxide coatings on Al alloys}

The catalytic activity of synthesized oxide systems $\mathrm{Al}_{2} \mathrm{O}_{3} \cdot \mathrm{CoO}_{\mathrm{x}}$ and $\mathrm{Al}_{2} \mathrm{O}_{3} \cdot \mathrm{MnO}_{\mathrm{x}}$ are tested in model reactions of $\mathrm{CO}$ and benzene oxidation ${ }^{20}$.

${ }^{20}$ Sakhnenko N.D., Ved M.V., Vestfrid Yu.V., Stepanova I.I. Predicting the catalytic activity of metal oxide systems in treatment of exhaust gases to remove nitrogen oxides. Russian Journal Applied Chemistry. 1996. Vol. 69. № 9. P. 1346-1350. 
Testing the catalytic activity of manganese and cobalt-containing oxide coatings showed that the ignition temperature, which corresponds to the beginning of effective catalyst operation, is in the range of $170-230^{\circ} \mathrm{C}$ for systems $\mathrm{Al} \mid \mathrm{Al}_{2} \mathrm{O}_{3} \cdot \mathrm{CoO}_{\mathrm{x}}$ and $\mathrm{Al} \mid \mathrm{Al}_{2} \mathrm{O}_{3} \cdot \mathrm{MnO}_{\mathrm{x}}$.

Oxide coatings doped with manganese provide a degree of $\mathrm{CO}$ conversion of $70 \%$, while for cobalt-containing oxide coatings this indicator is in the range of $81 \%$ (Figure 13).

The analysis of the obtained results leads to the conclusion that the formed oxide systems by catalytic activity are not inferior to the contacts with the content of precious metals $(\mathrm{Pt})$.

The developed technology has been tested for plasma-electrolytic treatment of ICE pistons. Oxide coatings doped with Co and Mn were obtained on the piston lid of the KamAZ-740 engine (Ukraine) ${ }^{21}$.

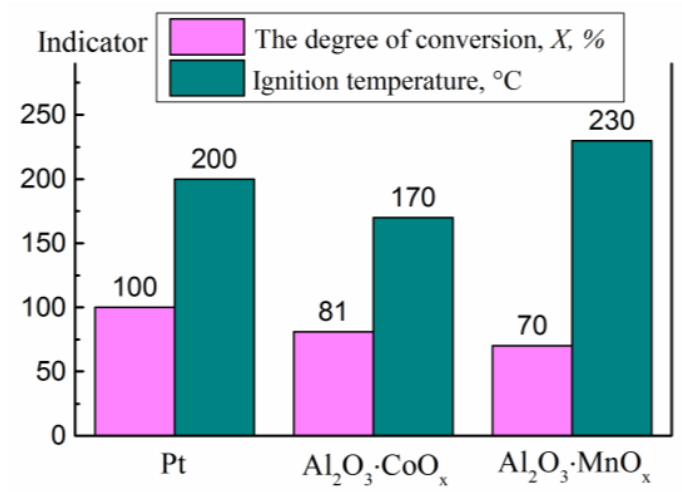

\section{Figures 13. Indicators of catalytic activity of materials}

Stand tests of single-cylinder diesel engine with catalytic coatings show a reduction in hourly fuel consumption and reduce toxic emissions at forced modes of engine operation. $\mathrm{Al}_{2} \mathrm{O}_{3} \cdot \mathrm{MnO}_{\mathrm{x}}$ coating demonstrates the highest fuel economy of $3-4 \%$. When using a piston with $\mathrm{Al}_{2} \mathrm{O}_{3} \cdot \mathrm{CoO}_{\mathrm{x}}$ coating, toxic gas emissions are reduced: $\mathrm{NO}_{\mathrm{x}}$ within $10 \%$ and $\mathrm{CO}-15-18 \%$.

It allows us to view them as promising materials for the intra-cylinder catalysis in order to reduce toxicity of engine emissions.

${ }^{21}$ Parsadanov I.V., Sakhnenko M.D., Khyzhnyak V.O., Karakurkchi H.V. Improving the environmental performance of engines by intra-cylinder neutralization of toxic exhaust gases.Internal Combustion Engines. 2016. № 2. P. 63-67. DOI:10.20998/04198719.2016.2.12

${ }_{22}$ Parsadanov I.V., Sakhnenko N.D., Ved M.V., Rykova I.V., Khyzhniak V.O., Karakurkchi A.V., Gorohivskiy A.S. Increasing the efficiency of intra-cylinder catalysis in diesel engines. Voprosy himii i himicheskoy tehnologii. 2017. Vol. 52. № 6. P. 145-151. 
Also, the manganese- and cobalt-containing oxide coatings, formed by the method of PEO on Al alloys could find application in the technology of ecological catalysis when used in the systems of air and water purification.

\section{Functional coatings on titanium alloys}

The oxide coatings formed in a diphosphate electrolyte in the presparking region (Fig. 1, I) are light-gray in color, which is typical of $\mathrm{TiO}_{2}$. This confirms indirectly data on the formation of a rutile $\mathrm{TiO}_{2}$ modification on titanium in the pre-sparking region in electrolytes of this type ${ }^{23}$. The oxide layer formed by PEO consists of the big rounded grains with the holes (doughnut like) and of the mixture of the fine acicular grains (Figure 14). The coating has the uniform chemical composition.

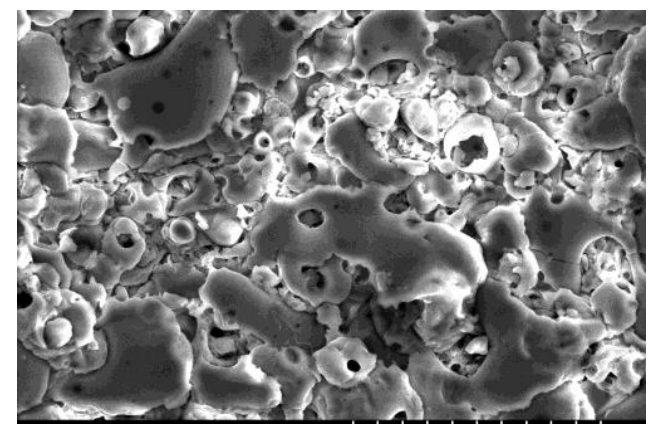

\section{Figure 14. Surface morphology of titanium with PEO coating, obtained in diphosphate electrolyte}

The $\mathrm{TiO}_{2}$ is prevailing in the pores, while potassium and phosphor oxides are formed on the toroid-like fragments of the structure ${ }^{24}$. In addition, surface layers include admixture contained in treated alloys (Figure 15).

The coating formed on the OT4-1 alloy has an explicit relief structure. It is less porous and contains alloying components in trace amounts.

As follows from Figure16, the applied conditions affect the layer structure. A uniform microglobular surface relief with the inclusion of fine needle grains is formed at a current density of $1.5 \mathrm{~A} / \mathrm{dm}^{2}$. Titanium oxide content in the surface layer is increased and the ratio of potassium at a constant concentration of phosphor is decreased.

\footnotetext{
${ }^{23}$ Gordienko P.S., Gnedenkov S.V. Plazmenno-elektroliticheskoe oksidirovanie titana i ego splavov. Vladivostok : Dalnauka. 1997. 344 p.

${ }^{24}$ Rokosz K., Hryniewicz T., Raaen S., Chapon P., Dudek L. GDOES, XPS, and SEM with EDS analysis of porous coatings obtained on titanium after plasma electrolytic oxidation. Surface and Interface Analysis. 2016. Vol. 49. № 4. P. 303-315. DOI: 10.1002/sia.6136.
} 



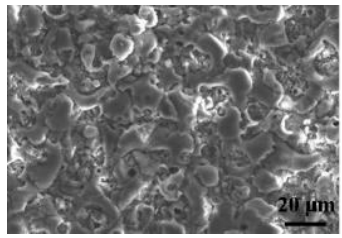

$\omega$, at. $\%$

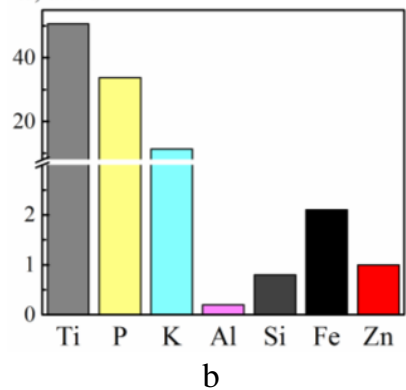

Figure 15. Morphology and content of the elements without oxygen in oxide coatings on alloys: $\mathrm{a}-\mathrm{VT1}-0 ; \mathrm{b}-\mathrm{OT} 4-1 . i=4 \mathrm{~A} / \mathrm{dm}^{2}$. Magnification $\times 1500$
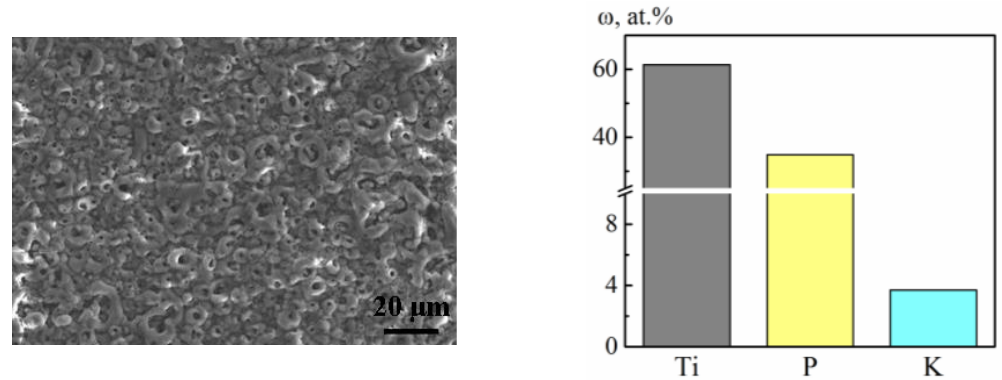

Figure 16. Effect of current density on morphology and compositionof PEO coating on Ti alloy. Magnification $\times 1500$

Therefore, varying the electrolyte composition, the current density and the PEO duration we can obtain the oxide coatings of a prescribed composition, morphology and thickness on the titanium alloys ${ }^{25}$.

${ }^{25}$ Sakhnenko N., Ved' M., Mayba M., Karakurkchi A. Galak A. Mixed Oxide Films Formed on Titanium Alloy by Plasma Electrolytic Oxidation. Surface Engineering and Applied Electrochemistry. 2018. Vol. 54. № 2. P. 203-209. DOI: $10.3103 / \mathrm{S} 1068375518020102$. 
A special interest to plasma electrolytic coatings on titanium is conditioned by the prospects of their use for the implants. It sets challenging requirements to the biocompatibility, the nontoxicity of surface layers and the adhesion stability. In addition, it is necessary to create such a surface relief that would provide a minimum friction and a minimum injure of the bone issue at a maximum rate of the growth of biotissues ${ }^{26}$.

Electrolyte compositions and electrolysis modes tested during the research enable the formation of coatings that satisfy all the criteria listed above.

An assessment of the surface topography of the oxidized titanium alloy indicates a relatively uniform roughness (Figure 17).


Figure 17. 3D-, 2D-surface maps of $\mathrm{TiO}_{2}$ coating and cross-section of the PEO- formed coatings of Ti alloy. The scan area is $5 \times 5 \mu \mathrm{m}$

The formed layer is a collection of rounded grains with evenly distributed pores. The grain size ranges from $600-700 \mathrm{~nm}$, and the height of the parabolic protrusions of the relief is $100-400 \mathrm{~nm}$. At the same time, the

${ }^{26}$ Wang Yi., Yu H., Chen Ch., Zhao Zh. Review of the biocompatibility of micro-arc oxidation coated titanium alloys. Materials \& design. 2015. Vol. 85. P. 640-652. DOI: 10.1016/j.matdes.2015.07.086. 
rounded shape of the grains ensures good glide. Such a relief provides maximum compatibility with biostructures ${ }^{27}$.

Therefore, using the PEO of titanium alloys in diphosphate electrolytes we can obtain oxide coatings of a different thickness depending on the treatment duration. The chemical and phase composition, the surface topography, the grain size can be controlled by varying the electrolyte concentration and the formation current density ${ }^{28,29}$.

The incorporation of dopants into the oxide layer of $\mathrm{TiO}_{2}$ substantially changes the composition and morphology of the surface ${ }^{30}$. The data of microscopic studies of the morphology of oxide coatings and are indicative of the formation of torus-like surface $\mathrm{TiO}_{2} \cdot \mathrm{CoO}_{\mathrm{x}}$ with a rather lower porosity (Figure18).
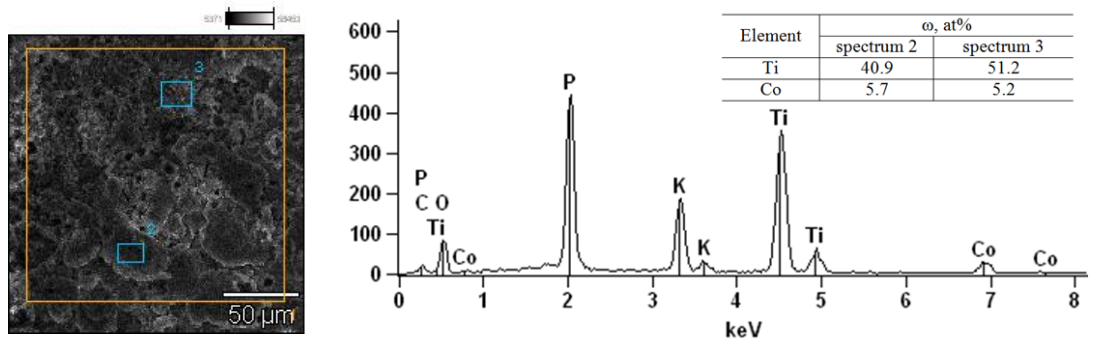

\section{Figure 18. Morphology and surface composition of oxide coatings $\mathrm{TiO}_{2} \cdot \mathrm{CoO}_{x}$}

The oxide coatings on $\mathrm{Ti}$ alloys with manganese are characterized by the presence of sharp edges and a smoothed surface relief (Figure 19).

It was established by AFM analysis that the PEOcoatings on Ti with manganese (cobalt) is microglobular and characterized by the high roughness and larger conglomerate sizes (Figure 20) compared to the $\mathrm{Ti} \mid \mathrm{TiO}_{2}$.

27 Krząkała A., Kazek-Kęsik A., Simka W. Application of plasma electrolytic oxidation to bioactive surface formation on titanium and its alloys. RSC Advances. 2013. Vol. 3. № 43. 19725. DOI: 10.1039/c3ra43465f.

${ }_{28}$ Vasilyeva M.S., Rudnev V.S. Composition, Surface Structure and Catalytic Properties of Manganese- and Cobalt-Containing Oxide Layers on Titanium. Advanced Materials Research. 2014. Vol. 875-877. P. 351-355. DOI: 10.4028/www.scientific.net/AMR.875-877.351.

${ }^{29}$ Shin K.R., Ko Y.G., Shin, D.H. Effect of electrolyte on surface properties of pure titanium coated by plasma electrolytic oxidation. Journal of Alloys and Compounds. 2011. Vol. 509. Suppl. 1. S. 478-481. DOI: 10.1016/j.jallcom.2011.02.056.

${ }^{30}$ Sakhnenko N.D., Ved M.V., Karakurkchi A.V. Effect of doping metals on the structure of PEO coatings on titanium. International Journal of Chemical Engineering. Vol. 2018. DOI: $10.1155 / 2018 / 4608485$. 

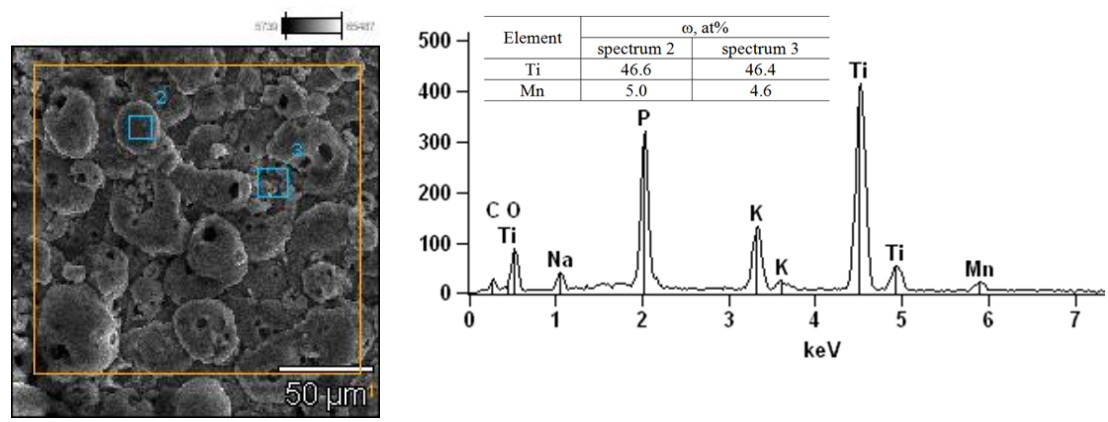

Figure 19.Morphology and surface composition of oxide coatings $\mathrm{TiO}_{2} \cdot \mathrm{MnO}_{\mathrm{x}}$
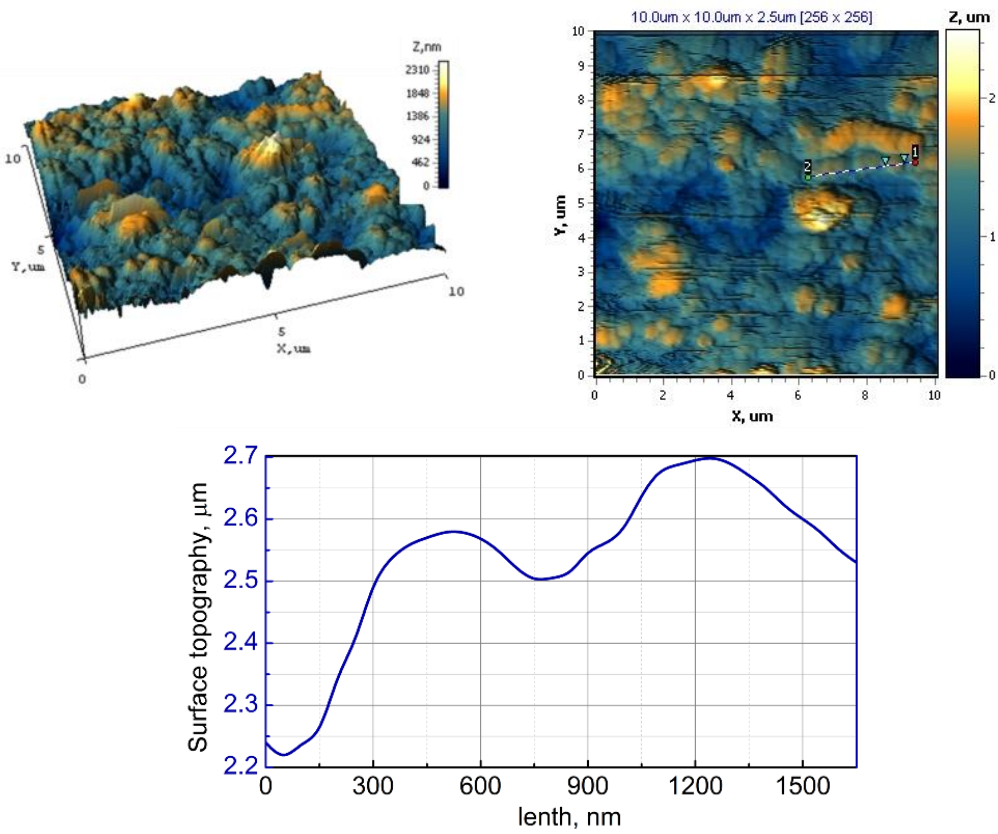

Figure 20. 3D- and 2D-surface maps and cross section profile of oxide coating $\mathrm{TiO}_{2} \cdot \mathrm{MnO}_{\mathrm{x}}$ on titanium alloy. Scanning area $10 \times 10 \mu \mathrm{m}$ 
Such a structure may provide the good substrate for the body cells deposition. In the case of artificial hip joint, the crucial parameter is a good sliding ability, which may be provided by the surface of a low roughness ${ }^{31}$.

The micro X-ray spectral analysis and the data of scanning electron microscopy show that in addition to $\mathrm{TiO}_{2}$ the coatings include the remelts of electrolyte components (Figure 19).

It should be noted that the analysis of the X-ray spectra obtained by the routine procedure shows the presence of the $\alpha-\mathrm{P}_{3} \mathrm{Ti}_{5}$ in the coatings. Furthermore, one can find small peaks at angles $2 \theta \sim 37^{\circ}$ and change in intensity double peaks at $2 \theta \sim 76^{\circ}$ on X-ray diffraction patterns of systems $\mathrm{TiO}_{2} \cdot \mathrm{CoO}_{\mathrm{x}}$ and $\mathrm{TiO}_{2} \cdot \mathrm{MnO}_{\mathrm{x}}$.

It may be concluded that this difference may be attributed with Co or Mn incorporation in titanium oxide matrix (Figure 21).

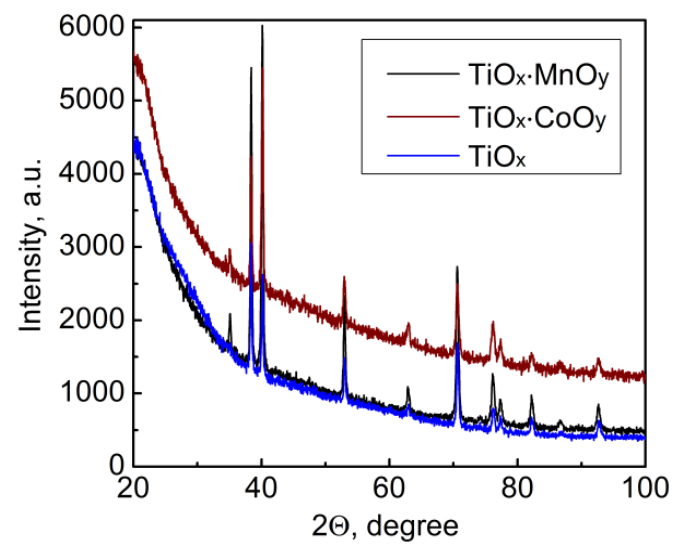

Figure 21. X-ray patterns of oxide coatings on titanium alloys

At the same time the low concentration of these elements does not allow to determine the phase composition with high accuracy.

The testing mixed manganese and cobalt containing oxides coatings show good catalytic activity ${ }^{32}$. In particular, by indicators of the ignition temperature and temperature of complete conversion obtainedoxidesystems with cobalt and manganesenot inferior to platinum-based catalysts (Table 2).

${ }^{31}$ Liang H., Shi B., Fairchild A., Cale T. S. Applications of plasma coatings in artificial joints: An overview. Vacuum. Vol. 73. № 3-4. P. 317-326. DOI: 10.1016/j.vacuum.2003.12.160.

${ }^{32}$ Sakhnenko N.D., Ved M.V., Karakurkchi A.V. Morphology and Properties of Coatings Obtained by Plasma-Electrolytic Oxidation of Titanium Alloys in Pyrophosphate Electrolytes. Protection of Metals and Physical Chemistry of Surfaces. 2017. Vol. 53. № 6. P. 1082-1090. DOI: 10.1134/S207020511706020X. 
The catalytic activity of the materials in the $\mathrm{CO}$ oxidation reaction

\begin{tabular}{|c|c|c|c|}
\hline $\begin{array}{c}\text { Catalyst } \\
\text { material }\end{array}$ & $\begin{array}{c}\text { The content of the active } \\
\text { ingredient } \boldsymbol{\omega}, \mathbf{a t} \%\end{array}$ & $\begin{array}{c}\text { Ignition } \\
\text { temperature } \\
\boldsymbol{T}_{\mathbf{i}}, \mathbf{K}\end{array}$ & $\begin{array}{c}\text { Temperature of } \\
\text { complete conversion } \\
\boldsymbol{T}_{\mathbf{c}}, \mathbf{K}\end{array}$ \\
\hline $\mathrm{Pt}$ & 100 & 495 & 650 \\
\hline $\mathrm{TiO}_{2} \cdot \mathrm{CoO}_{\mathrm{x}}$ & $\mathrm{Co}-6.3$ & $565-570$ & $700-710$ \\
\hline $\mathrm{TiO}_{2} \cdot \mathrm{MnO}_{\mathrm{x}}$ & $\mathrm{Mn}-5.0$ & $510-520$ & $670-675$ \\
\hline
\end{tabular}

The oxide layer formed considerably increases the corrosion resistance of titanium in alkaline and acid media and also in Ringer solutions ${ }^{33}$. It is important enough to use these coatings for the bio-applications.

\section{CONCLUSIONS}

Plasma-electrolytic oxidation of aluminum and titanium alloys in diphosphate electrolytes with the addition of cobalt and manganese salts makes it possible to obtain coatings with mixed oxides, the composition and morphology of which are governed by the ratio of the electrolyte components and the current density.

Mixed oxide systems differ in the developed microglobular surface, the relief of which depends on the nature of the base metal and the dopant. Synthesized materials $\mathrm{Al}\left|\mathrm{Al}_{2} \mathrm{O}_{3} \cdot \mathrm{CoO}_{\mathrm{x}}, \mathrm{Al}\right| \mathrm{Al}_{2} \mathrm{O}_{3} \cdot \mathrm{MnO}_{\mathrm{y}}, \mathrm{Ti} \mid \mathrm{TiO}_{2} \cdot \mathrm{CoO}_{\mathrm{x}}$, $\mathrm{Ti} \mid \mathrm{TiO}_{2} \cdot \mathrm{MnO}_{\mathrm{x}}$ have high corrosion resistance and catalytic properties that are not inferior to platinum metals. These systems could find effective application in the technologies of ecological catalysis during neutralization of toxic components.

\section{SUMMARY}

The paper presents the results of studies the electrochemical treatment characteristics of aluminum and titanium alloys in alkaline electrolytes. For homogenization of the treated surface and formation of oxide coatings doped with $\mathrm{Mn}$ i Co diphosphate electrolytes the addition of $\mathrm{KMnO}_{4}$ and $\mathrm{CoSO}_{4}$ were used. Formed mixed oxide systems on $\mathrm{Al}$ and $\mathrm{Ti}$ alloys have a developed surface, high adhesion to the base metal, and also exhibit increased corrosion resistance and catalytic activity. They can be used in airand water purification, as well as in the exhaust gas cleaning systems of engines.

The prospect of further research may be related to the adaptation of the proposed technology for surface treatment of other structural materials and the expansion of the range of used dopants. This will increase the efficiency

${ }^{33}$ Lunarska E., Cherniayeva O., Ved M., Sakhnenko M. Oxide film formed on Ti by the microark anodic method. Ochronaprzed Korozja. 2007. № 11A. P. 265-269. 
of the method of surface electrochemical treatment and expand the scope of use of mixed oxide systems.

\section{REFERENCES}

1. Gupta P., Tenhundfeld E. O., Daigle D., Ryabkov G. Electrolytic plasma technology: Science and engineering - An overview. Surface and Coatings Technology. 2007. Vol. 201, Issue 21. P. 8746-8760. DOI: 10.1016/j.surfcoat.2006.11.023.

2. Rudnev V.S., Lukiyanchuk I.V., Vasilyeva M.S., Medkov M.A., Adigamova M.V., Sergienko V.I. Aluminum- and titanium-supported plasma electrolytic multicomponent coatings with magnetic, catalytic, biocide or biocompatible properties. Surface \& Coatings Technology. 2016. Vol. 307. Part C. P. 1219-1235. DOI:10.1016/j.surfcoat.2016.07.060.

3. Malyshev, V.N., Zorin, K.M. Features of Microarc Oxidation Coatings Formation Technology in Slurry Electrolytes. Applied Surface Science. 2007. № 254 (5). P. 1511-1516. DOI: 10.1016/j.apsusc.2007.07.079.

4. Suminov, I.V., Belkin, P.N., Epelfeld, A.V., Lyudin, V.B., Krit, B.L., Borisov, A.M. Plazmenno-elektroliticheskoe modifitsirovanie poverhnosti metallov i splavov. Moskow : Tehnosfera, 2011. T. 1. 464 p.

5. Sakhnenko N.D., Ved M.V., Karakurkchi A.V. Nanoscale Oxide PEO Coatings Forming from Diphosphate Electrolytes. Springer Proceedings in Physics. 2017. P. 507-531. DOI: 10.1007/978-3-319-564227_38.

6. Yar-Mukhamedova, G.Sh., Ved, M.V., Karakurkchi, A.V., Sakhnenko, N.D. Mixed alumina and cobalt containing plasma electrolytic oxide coatings. IOP Conference Series: Materials Science and Engineering. 2017. Vol. 213. DOI:10.1088/1757-899X/213/1/012020.

7. Yar-Mukhamedova G., Ved M., Karakurkchi A., Sakhnenko N., Atchibayev R. Research on the improvement of mixed titania and Co (Mn) oxide nano-composite coatings. IOP Conference Series: Materials Science and Engineering. 2018. Vol. 369. 012019. DOI: 10.1088/1757$899 X / 369 / 1 / 012019$.

8. Terleeva O.P., Belevantsev V.I., Slonova A.I., Boguta D.L., Rudnev V.S. Comparison analysis of formation and some characteristics of microplasma coatings on aluminum and titanium alloys. Protection of Metals. 2006. Vol. 42. № 3. P. 272-278. DOI: 10.1134/S0033173206030106.

9. Sakhnenko M., Ved' M., Gorohivskiy A., Galak O., Menshov S., Matykin O. Cobalt and manganese oxide catalytic systems on valve metals in ecotechnologies. Promising Materials and Processes in Applied Electrochemistry : monograph / editor-in-chief V.S. Barsukov. Kyiv, 2017. P. 214-223. 
10. Ved M.V., Karakurkchi A.V., Sakhnenko N.D., Gorohivskiy A.S. Synthesis of catalytic cobalt-containing coatings on alloy AL25 surface by plasma electrolytic oxidation. Chemistry, Physics and Technology of Surface. 2017. Vol. 8. № 1. P. 73-79. DOI: 10.15407/hftp08.01.073.

11. Sakhnenko N.D., Ved' M.V., Luhovskyi I.S., Drobakha H.A., Mayba M.V. Features of plasma electrolytic formation of manganese- And cobalt-containing composites on aluminum alloys. Advances in Materials Science and Engineering. 2019. Vol. 2019. Article ID 6381291. 13 p. DOI: $10.1155 / 2019 / 6381291$.

12. Karakurkchi A., Sakhnenko M., Ved M., Galak A., Petrukhin S. Application oxide-metall catalysts on valve metals in environmental catalysis. Eastern-European Journal of Enterprise Technologies. Materials

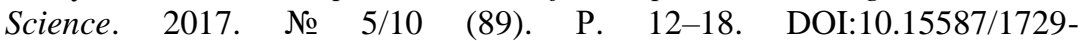
4061.2017.109885.

13. Rogov A.B. Plasma electrolytic oxidation of A1050aluminium alloy in homogeneous silicate-alkaline electrolytes with edta 4-complexes of $\mathrm{Fe}$, $\mathrm{Co}, \mathrm{Ni}, \mathrm{Cu}, \mathrm{La}$ and $\mathrm{Ba}$ under alternating polarization conditions. Materials Chemistry and Physics. 2015. Vol. 167. P. 136-144. DOI: 10.1016/j.matchemphys.2015.10.020.

14. Walsh F.C., Low C.T.J., Wood R.J.K., Stevens K.T., Archer J., PoetonA.Rl. Plama electrolytic oxidizing (PEO) for production of anodised coatings on lightweight metal $(\mathrm{Al}, \mathrm{Mg}, \mathrm{Ti})$ alloys. Transactions of the Institute of Metal Finishing. 2009. Vol. 87. № 3. P. 122-135. DOI: 10.1179/174591908X372482.

15. Ved' M.V., Sakhnenko N.D., Karakurkchi A.V., Myrna T.Yu. Functional mixed cobalt and aluminum oxide coatings for environmental safety. Functional Materials. 2017. Vol. 24. № 2. P. 303-310. DOI: 10.15407/fm24.02.303.

16. Egorkin V.S., Vyaliy I.E., Sinebryukhov S.L., Gnedenkov S.V. Composition, morphology and tribological properties of PEO-coatings formed on an aluminum alloy D16 at different duty cycles of the polarizing signal. Non-ferrous Metals. 2017. Vol. 42. № 1. P. 12-16.

17. Sakhnenko N.D., Ved M.V., Androshchuk D.S., Korniy S.A. Formation of coatings of mixed aluminum and manganese oxides on the AL25 alloy. Surface Engineering and Applied Electrochemistry. 2016. Vol. 52. № 2. P. 145-151. DOI: 10.3103/s1068375516020113.

18. Yerokhin A.L., Nie X., Leyland A., Matthews A., Dowey S.J. Plasma electrolysis for surface engineering. Surface and Coating Technology. 1999. Vol. 122. № 2-3. P. 73-93. DOI: 10.1016/s0257-8972(99)00441-7.

19. Sakhnenko N.D., Ved M.V., Vestfrid Yu.V., Stepanova I.I. Predicting the catalytic activity of metal oxide systems in treatment of 
exhaust gases to remove nitrogen oxides. Russian Journal Applied Chemistry. 1996. Vol. 69. № 9. P. 1346-1350.

20. Parsadanov I.V., Sakhnenko M.D., Khyzhnyak V.O., Karakurkchi H.V. Improving the environmental performance of engines by intra-cylinder neutralization of toxic exhaust gases. Internal Combustion Engines. 2016. № 2. P. 63-67. DOI: 10.20998/0419-8719.2016.2.12.

21. Parsadanov I.V., Sakhnenko N.D., Ved M.V., Rykova I.V., Khyzhniak V.O., Karakurkchi A.V., Gorohivskiy A.S. Increasing the efficiency of intra-cylinder catalysis in diesel engines. Voprosy himii $i$ himicheskoy tehnologii. 2017. Vol. 52. № 6. P. 145-151.

22. Gordienko P.S., Gnedenkov S.V. Plazmenno-elektroliticheskoe oksidirovanie titana i ego splavov. Vladivostok: Dalnauka. 1997. 344 p.

23. Rokosz K., Hryniewicz T., Raaen S., Chapon P., Dudek L. GDOES, XPS, and SEM with EDS analysis of porous coatings obtained on titanium after plasma electrolytic oxidation. Surface and Interface Analysis. 2016. Vol. 49. № 4. P. 303-315. DOI: 10.1002/sia.6136.

24. Sakhnenko N., Ved' M., Mayba M., Karakurkchi A. Galak A. Mixed Oxide Films Formed on Titanium Alloy by Plasma Electrolytic Oxidation. Surface Engineering and Applied Electrochemistry. 2018. Vol. 54. № 2. P. 203-209. DOI: 10.3103/S1068375518020102.

25. Wang Yi., Yu H., Chen Ch., Zhao Zh. Review of the biocompatibility of micro-arc oxidation coated titanium alloys. Materials \& design. 2015. Vol. 85. P. 640-652. DOI: 10.1016/j.matdes.2015.07.086

26. Krząkała A., Kazek-Kęsik A., Simka W. Application of plasma electrolytic oxidation to bioactive surface formation on titanium and its alloys. RSC Advances. 2013. Vol. 3. № 43. DOI: 10.1039/c3ra43465f.

27. Vasilyeva M.S., Rudnev V.S. Composition, Surface Structure and Catalytic Properties of Manganese- and Cobalt-Containing Oxide Layers on Titanium. Advanced Materials Research., 2014. Vol. 875-877. P. 351-355. DOI: 10.4028/www.scientific.net/AMR.875-877.351.

28. Shin K.R., Ko Y.G., Shin, D.H. Effect of electrolyte on surface properties of pure titanium coated by plasma electrolytic oxidation. Journal of Alloys and Compounds. 2011. Vol. 509. Suppl. 1. S. 478-481. DOI: 10.1016/j.jallcom.2011.02.056.

29. Sakhnenko N.D., Ved M.V., Karakurkchi A.V. Effect of doping metals on the structure of PEO coatings on titanium. International Journal of Chemical Engineering. Vol. 2018. DOI: 10.1155/2018/4608485.

30. Liang H., Shi B., Fairchild A., Cale T.S. Applications of plasma coatings in artificial joints: An overview. Vacuum. Vol. 73. № 3-4. P. 317-326. DOI: 10.1016/j.vacuum.2003.12.160.

31. Sakhnenko N.D., Ved M.V., Karakurkchi A.V. Morphology and Properties of Coatings Obtained by Plasma-Electrolytic Oxidation of 
Titanium Alloys in Pyrophosphate Electrolytes. Protection of Metals and Physical Chemistry of Surfaces. 2017. Vol. 53. № 6. P. 1082-1090. DOI: 10.1134/S207020511706020X.

32. Lunarska E., Cherniayeva O., Ved M., Sakhnenko M. Oxide film formed on Ti by the microark anodic method. Ochronaprzed Korozja. 2007. № 11A. P. 265-269.

\section{Information about authors:} Karakurkchi H. V., Candidate of Technical Sciences, Department of Physical Chemistry Institute of Education and Science in Chemical Technologies and Engineering National Technical University "Kharkiv Polytechnic Institute" 2, Kyrpychova str., Kharkiv, 61002, Ukraine

Sakhnenko M. D., Doctor of Technical Sciences, Professor,

Department of Physical Chemistry Institute of Education and Science in Chemical Technologies and Engineering National Technical University "Kharkiv Polytechnic Institute" 2, Kyrpychova str., Kharkiv, 61002, Ukraine 